\title{
EFFECT OF LYSOZYME OR NISIN ON SURVIVAL OF SOME BACTERIA TREATED WITH HIGH PRESSURE AT SUBZERO TEMPERATURE
}

\author{
Edyta Malinowska-Pańczyk, Ilona Kołodziejska*
}

Department of Food Chemistry, Technology and Biotechnology, Chemical Faculty, Gdansk University of Technology

G. Narutowicza 11/12, 80-952 Gdańsk, Poland.

Submitted: June 25, 2008; Returned to authors for corrections: October 12, 2008; Approved: July 14, 2009.

\begin{abstract}
The aim of this work was to examine the inactivation of some Gram-positive and Gram-negative bacteria exposed to the pressure of $193 \mathrm{MPa}$ at $-20^{\circ} \mathrm{C}$ in the presence of lysozyme or nisin at concentration of $400 \mu \mathrm{g} / \mathrm{ml}$. The highest effect of pressure at subzero temperature and lysozyme was found with pressure sensitive Pseudomonas fluorescens; viable cells of this strain were not detected in $1 \mathrm{ml}$ of sample after combined treatment. The action of pressure at subzero temperature and lysozyme or nisin against Escherichia coli led to synergistic reduction by 0.7 or $1.6 \log$ cycles, respectively, while it was practically insignificant for two Staphylococcus aureus strains. Viability loss of E. coli and S. aureus occurred during storage for $20 \mathrm{~h}$ of the samples at 37 and $5{ }^{\circ} \mathrm{C}$, which were previously pressurized with lysozyme or nisin. The synergistic effect of pressure and nisin at $\mathrm{pH} 5$ against $E$. coli cells just after the pressure treatment was lower than that at $\mathrm{pH} 7$, however, the extent of the lethal effect after storage was higher.
\end{abstract}

Key words: Inactivation of microorganisms, High pressure, Subzero temperature, Lysozyme, Nisin

\section{INTRODUCTION}

High-pressure technique is commercially used for preservation of, mainly, acid food products. However, food with $\mathrm{pH}$ close to neutral is a better medium for growth of microorganisms that survived the pressure treatment. Moreover, frequently in the pressure treated population of vegetative bacteria survivor tails can occur (35). It is known that Gram-negative bacteria and cells in the exponential growth phase are more sensitive to pressure treatment than Gram-positive bacteria and cells being in the stationary phase of growth $(3,35)$. Moreover, species very resistant to high pressure exist even among Gram-negative bacteria. Variations in pressure resistance were also observed among strains belonging to the same species of food-born pathogens and spoilage bacteria $(1,21,28,29)$. It should be also taken

\footnotetext{
*Corresponding Author. Mailing address: Department of Food Chemistry, Technology and Biotechnology Chemical Faculty, Gdansk University of Technology, G. Narutowicza 11/12, 80-952 Gdańsk, Poland.; Fax: +48-58-3472694.; E-mail: i.kolodziejska@ @hem.pg.gda.pl
} 
into consideration that barotolerant mutants can be formed in the pressure process (14). Furthermore, microorganisms are usually more resistant to pressure treatment in food systems than in a buffer $(4,8,29,34)$. For these reasons pressure above the moderate range should be used in cold pasteurization of food. This could limit the practical applications of this technique due to changes in some components of food, especially proteins and because of the higher operating costs with the increase of pressure dose. One of the possibilities for achieving the increase in inactivation of bacteria in low-acidity foods is using pressure in combination with antimicrobial factors. Lysozyme, lactoperoxidase, lactoferrin, lactoferricin, nisin and pediocin are known to enhance the effectiveness of high pressure in inactivation of some bacteria $(8,9,10,17,18,19,20,22,24$, 27). The synergistic effect is a result of sublethal injury of cells that makes them more sensitive to antimicrobial substances $(14,17,18,20)$. Moreover, the high pressure induces outer membrane permeabilization in Gram-negative bacteria. It sensitizes the cells to action of bacteriocins and lysozyme $(14,22,23,27)$. The temperatures used in experiments conducted by the cited authors were in the range of $20-50{ }^{\circ} \mathrm{C}$. However, Steeg et al. (36) observed the enhanced synergistic inactivation of some bacteria when high pressure in the presence of nisin was used at temperature $10{ }^{\circ} \mathrm{C}$. This effect of nisin can probably deepen during further reduction of temperature. Moreover, the limited available data showed higher level of inactivation of microorganisms under high pressure at subzero temperature than in a certain range of temperature above $0{ }^{\circ} \mathrm{C}(12,15,26,31,32,33)$.

Therefore, it is not excluded that such conditions may enhance the synergistic effect of combined action of high pressure and nisin against microorganisms. Furthermore, it would be worth also to check if lysozyme exerts any antimicrobial activity under pressure at such low temperature as $-20{ }^{\circ} \mathrm{C}$. It is known that this polypeptide can act on bacteria according to lytic and non-lytic mechanisms, depending on their type and the environmental conditions (6, 25). Therefore, the aim of this work was to examine the inactivation of some Gram-positive and Gram-negative bacteria exposed to pressure of about $193 \mathrm{MPa}$ at $-20{ }^{\circ} \mathrm{C}$ in unfrozen system in the presence of lysozyme and nisin followed by prolonged storage at 5 and $37^{\circ} \mathrm{C}$. Such data were not found in the available literature.

\section{MATERIALS AND METHODS}

\section{Preparation of lysozyme and nisin solutions}

Hen egg white lysozyme (69 480 U/mg proteins, Fluka, Switzerland) dissolved in potassium phosphate buffer (10 mM, pH 7.0) at concentration of $2 \mathrm{mg} / \mathrm{ml}$ and nisin (Fluka, Switzerland) dissolved in $0.01 \mathrm{M} \mathrm{HCl}$ at concentration of $2 \mathrm{mg} / \mathrm{ml}$, prepared directly before experiments, were used.

\section{Cultures and growth conditions}

The following bacterial strains were used: Pseudomonas fluorescens WSRO121 from Collection of Dairy Cultures of Department of Microbiology, University of Warmia and Mazury, Olsztyn, Poland; Escherichia coli K-12 PCM2560 (NCTC10538) and Staphylococcus aureus PCM2054 (ATCC25923) from Polish Collection of Microorganisms, Ludwik Hirszfeld Institute of Immunology and Experimental Therapy of the Polish Academy of Sciences, Wrocław, Poland; Staphylococcus aureus DSM2569 from German Collection of Microorganisms and Cell Cultures and Listeria innocua $\mathrm{III}_{1}$ (isolated from fish) kindly provided by Department of Food Microbiology, University of Agriculture, Szczecin, Poland.

Inocula of strains were prepared by inoculating $100 \mathrm{ml}$ 
of tripticase soy broth supplemented with $0.6 \%$ yeast extract (TSBYE; purchased from BTL Sp. z o.o., Łódź, Poland) with $100 \mu \mathrm{l}$ of liquid culture (at stationary phase of growth) and incubating at $37^{\circ} \mathrm{C}$ (E. coli, S. aureus, L. innocua $)$ or $28^{\circ} \mathrm{C}$ (P.fluorescens) for $24 \mathrm{~h}$ with shaking. Under these conditions the cells were in the stationary phase.

In order to obtain an appropriate growth phase of cells, $100 \mu \mathrm{l}$ of the stationary-phase culture were inoculated into $100 \mathrm{ml}$ of fresh TSBYE and incubated with shaking at optimal temperature of growth for particular microorganisms. The bacteria growth was measured by determination of optical density at $660 \mathrm{~nm}$ for $48 \mathrm{~h}$. The middle exponential and stationary phase were determined from the obtained curves of growth.

\section{Preparation of cell suspensions}

The cells in a stationary or exponential phase of growth were centrifuged at $1300 \mathrm{xg}$ for $20 \mathrm{~min}$ at $5{ }^{\circ} \mathrm{C}$, and the pellets were resuspended in phosphate-buffered saline at $\mathrm{pH} 7.0$ or in some experiments in Mc Ilvaine's buffer at $\mathrm{pH} 5.0$ to give viable counts of about $10^{8} / 10^{9} \mathrm{cfu} / \mathrm{ml}$. Antimicrobials were added to the final concentration of $400 \mu \mathrm{g} / \mathrm{ml}$ (lysozyme) or 100 and $400 \mu \mathrm{g} / \mathrm{ml}$ (nisin).

\section{Pressure treatment}

The pressure was generated similarly as described by Hayakawa et al. (15). The procedure was based on the phenomenon that in a sealed vessel filled with water and kept at subzero temperatures, increasing volume of forming ice I generates internal pressure. According to Bridgman (2) high pressure reduces the freezing and melting points of water to a minimum of $-22{ }^{\circ} \mathrm{C}$ at $207.5 \mathrm{MPa}$. Therefore, above this temperature, the sample placed in a sealed vessel is affected by the pressure in unfrozen state.

The equipment used to generate pressure during the experiments was designed and constructed by Edward
Dunajski in our Department (Fig. 1).

Cell suspensions ( $3 \mathrm{ml}$ of each) were placed in sterile glass test tubes (with volume of $3 \mathrm{ml}$ ), and sealed with a stopper. At this moment a small excess of liquid was pushed out from the tubes without leaving any bubbles of air inside. Due to the special design the stopper holds the tightness of the tube and it is able to move. This allows to expose the sample to the generated pressure.

The tube containing cell suspension and then a metal spring were placed in a cylindrical metal vessel filled with distilled water. The vessel was closed without leaving any bubbles of air inside. It was immersed in four stages during $40 \min (4 \times 10 \mathrm{~min})$ with the closed side down, in a temperature-controlled bath containing a mixture of ethanol, propylene glycol and distilled water $(1: 1: 1, \mathrm{v} / \mathrm{v})$ as a coolant (Fig. 1). So initially, only the bottom part of the vessel was immersed in the cooling bath. The role of the spring was to keep the tube, at this moment and later, when the whole pressure vessel was in the cooling mixture, at upper nonfrozen zone - of the pressure vessel. The time during which the assumed temperature was achieved has been determined in preliminary experiments using a thermocouple. As high pressure lowers the freezing point of water, thus the material should be in the unfrozen state up to about $-20^{\circ} \mathrm{C}$. This fact confirmed the results of experiments in which hydrogels were kept at $-20{ }^{\circ} \mathrm{C}$ in the pressure vessel and simultaneously at the same temperature under atmospheric pressure. The damage of structure of the latter hydrogel caused by water crystallization was visible. Such changes did not appear when hydrogel was cooled in the sealed vessel.

After pressure treatment at $-20{ }^{\circ} \mathrm{C}$ the vessel was stuck out from cooling bath in half of its length and warmed in the upper part to $15^{\circ} \mathrm{C}$ measured with a thermocouple. Then the vessel was taken out and placed for a few minutes in a water bath at $20{ }^{\circ} \mathrm{C}$. The total time of decompression did not exceed $10 \mathrm{~min}$. The samples were stored in an ice bath prior to 
Malinowska-Pańczyk, E. et al.

determination of viable counts. Unpressurized samples were used as controls. In some experiments the samples were incubated for 2 or $20 \mathrm{~h}$ with or without lysozyme/nisin added after the pressure treatment.

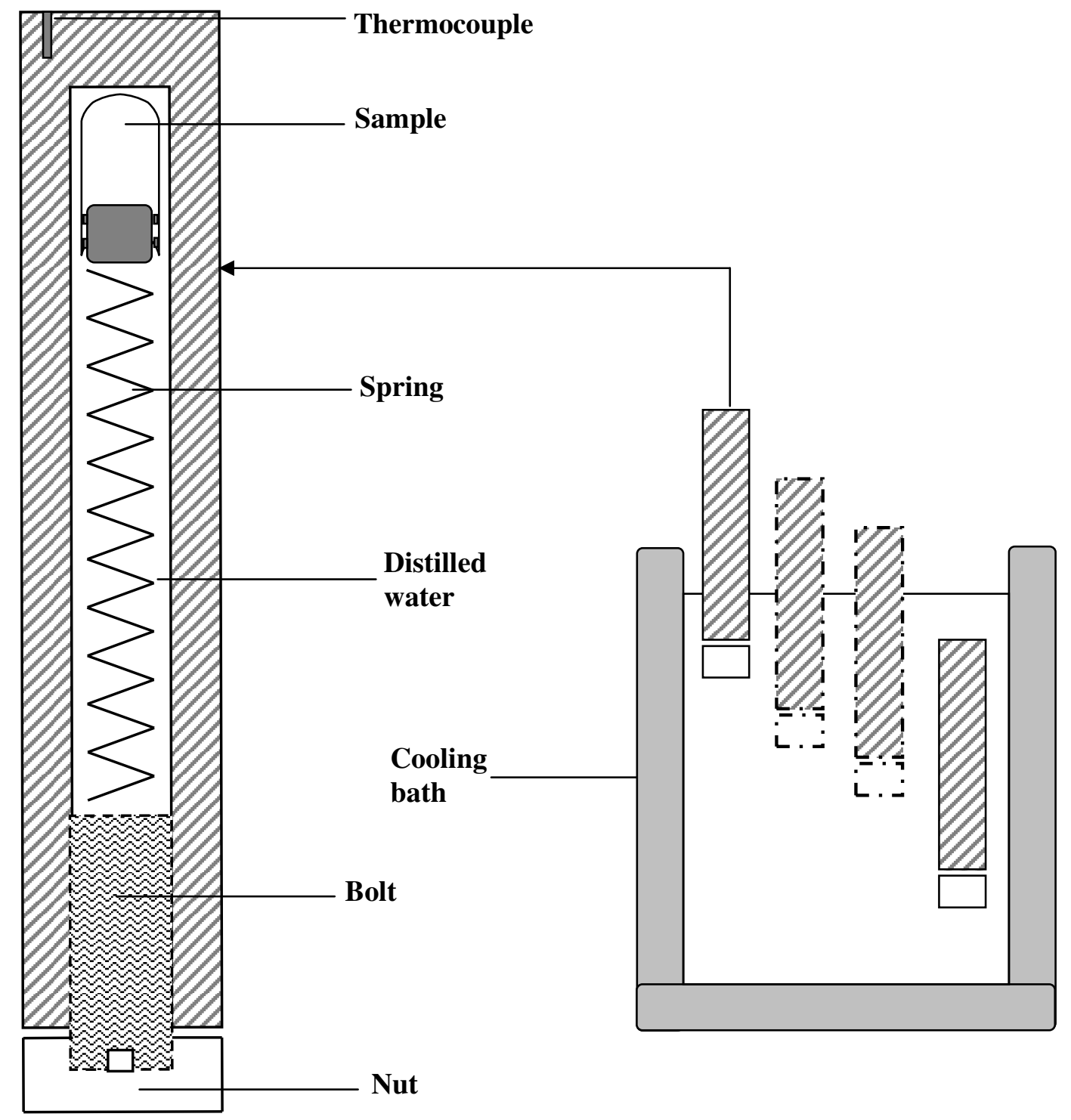

Figure 1. Scheme of the high pressure vessel and sample installation

\section{Enumeration of viable cells}

Pressure-treated samples and untreated control cell suspensions were serially diluted with buffered saline $(\mathrm{pH}$ 7.0). Dilutions were plated on tripticase soy agar supplemented with $0.6 \%$ yeast extract (TSAYE; purchased from BTL Sp. z o.o., Łódź, Poland)) and plates were incubated for $48 \mathrm{~h}$ at $37^{\circ} \mathrm{C}$ (E. coli, S. aureus, L. innocua) or $28{ }^{\circ} \mathrm{C}$ (P. fluorescens). 
The data presented in the tables and figures are mean values obtained from three independent experiments. The bars on the figures indicate the mean standard deviations for the data points. The results were evaluated statistically by analysis of variance (one-way procedure) or Students t-test using the program Statgraphics, Statistical Graphic Corporation.

\section{RESULTS AND DISCUSSION}

\section{Antibacterial effect of high pressure and lysozyme}

The pressure that can be achieved at $-20{ }^{\circ} \mathrm{C}$ in the closed vessel amounts to about $193 \mathrm{MPa}$. The tested bacteria differed in sensitivity to pressure mainly in the exponential phase of growth and the most pressure resistant were $S$. aureus strains (Fig. 2). The number of viable cells from the stationary phase of growth decreased under these conditions no more than by one log cycle, with exception of $P$. fluorescens. The pressure reduction in the viability of this strain was about $4 \log$ cycles. The large pressure sensitivity of P. fluorescens was also evidenced by Gervilla et al. (11). Therefore, in the next experiments only bacterial cells in the stationary phase of growth were used.

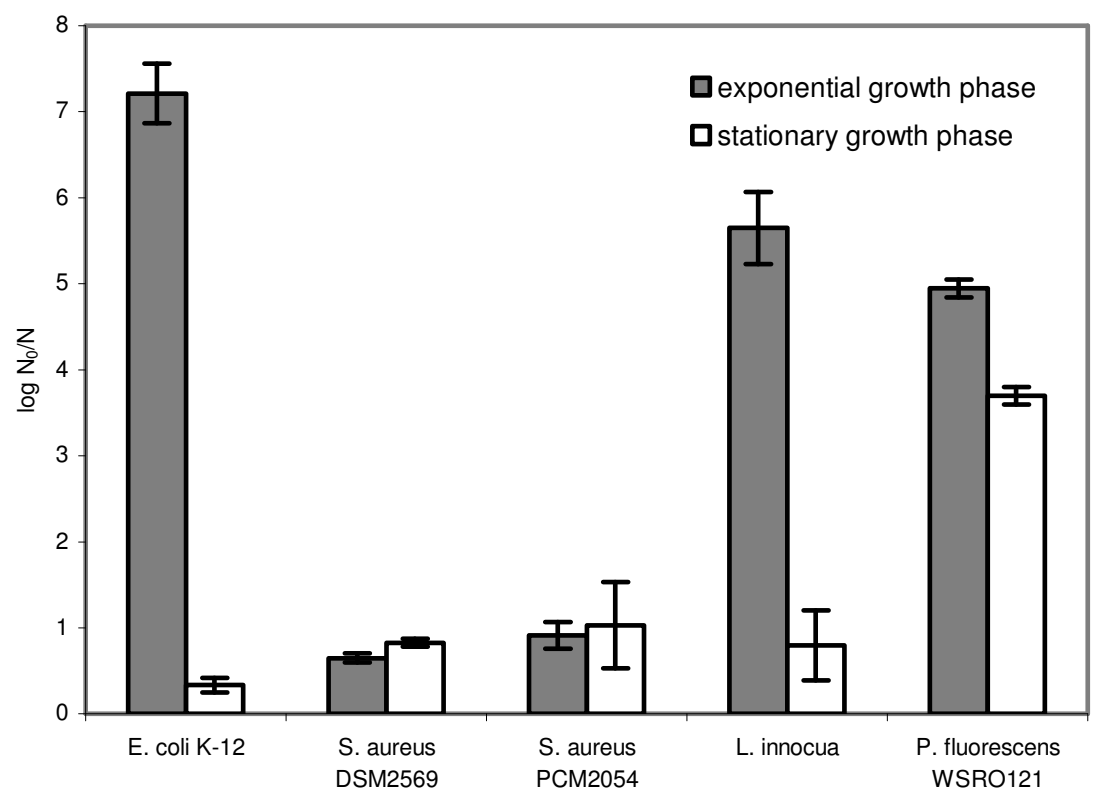

Figure 2. Viability loss of some Gram-negative and Gram-positive bacteria after pressure treatment at $193 \mathrm{MPa}$ and $-20{ }^{\circ} \mathrm{C}$ $\mathrm{N}_{0}$ - the number of cells in the control (about $10^{8}-10^{9} \mathrm{cfu} / \mathrm{ml}$ ) $\mathrm{N}$ - the number of cells detected after pressurization

As expected, lysozyme at ambient pressure was not effective against Gram-negative bacteria: E. coli and $P$. fluorescens (Table 1). Moreover, the viability loss in the presence of lysozyme in the case of tested Gram-positive $L$. innocua and two strains of $S$. aureus did not exceed $0.5 \mathrm{log}$ cycle. As reported by Pellegrini et al. (30) lysozyme at atmospheric pressure did not attack S. aureus ATCC 25923 and S. epidermidis ATCC 1228 cells. It is known that modification of the peptidoglycan of some Gram-positive bacteria results in resistance to its degradation by lysozyme (5).

When combined pressure $193 \mathrm{MPa}$ at $-20{ }^{\circ} \mathrm{C}$ and lysozyme were used the extra reduction of E. coli of $0.7 \mathrm{log}$ cycle was obtained (Fig. 3). In samples pressurized in the 
presence of lysozyme the viability of $E$. coli cells did not decrease during incubation for $2 \mathrm{~h}$ at $37^{\circ} \mathrm{C}$ (Fig. $3 \mathrm{~B}$ and C). Moreover, there were no significant differences in the number of viable cells in the pressurized samples without lysozyme and in the samples incubated for $2 \mathrm{~h}$ at $37^{\circ} \mathrm{C}$ with lysozyme added after pressure treatment (Fig. 3 A and D). These data suggest that some of the observed antimicrobial impact of lysozyme did not take place after decompression but during pressurization at subzero temperature. Lysozyme probably does not show enzyme activity at $-20{ }^{\circ} \mathrm{C}$; thus a non-lytic mechanism of lysozyme action under these conditions could not be excluded. The most likely non-lytic mechanism of antimicrobial activity of lysozyme is based on disruption of bacterial membrane (6).

Table 1. The viability of some Gram-negative and Grampositive bacteria of stationary phase after $2 \mathrm{~h}$ incubation at $37^{\circ} \mathrm{C}$ in the presence of lysozyme $(400 \mu \mathrm{g} / \mathrm{ml})^{1}$.

\begin{tabular}{lcc}
\hline \multirow{2}{*}{ Strain } & \multicolumn{2}{c}{ Log CFU/ml } \\
\cline { 2 - 3 } & $\begin{array}{c}\text { Without } \\
\text { lysozyme }\end{array}$ & $\begin{array}{c}\text { With } \\
\text { lysozyme }\end{array}$ \\
\hline S. aureus PCM2054 & $8.9 \pm 0.1^{\mathrm{a}}$ & $8.5 \pm 0.1^{\mathrm{b}}$ \\
S. aureus DSM2569 & $8.8 \pm 0.1^{\mathrm{a}}$ & $8.7 \pm 0.0^{\mathrm{a}}$ \\
E. coli $\mathrm{K}-12$ & $8.8 \pm 0.1^{\mathrm{a}}$ & $8.8 \pm 0.1^{\mathrm{a}}$ \\
L. innocua III $_{1}$ & $8.6 \pm 0.1^{\mathrm{a}}$ & $8.1 \pm 0.1^{\mathrm{b}}$ \\
P. fluorescens WSRO121 & $8.8 \pm 0.1^{\mathrm{a}}$ & $8.6 \pm 0.1^{\mathrm{a}}$ \\
\hline${ }^{\mathrm{T}}$ The values for a particular row followed by different letters differ
\end{tabular}
significantly $(\mathrm{p}<0.05)$
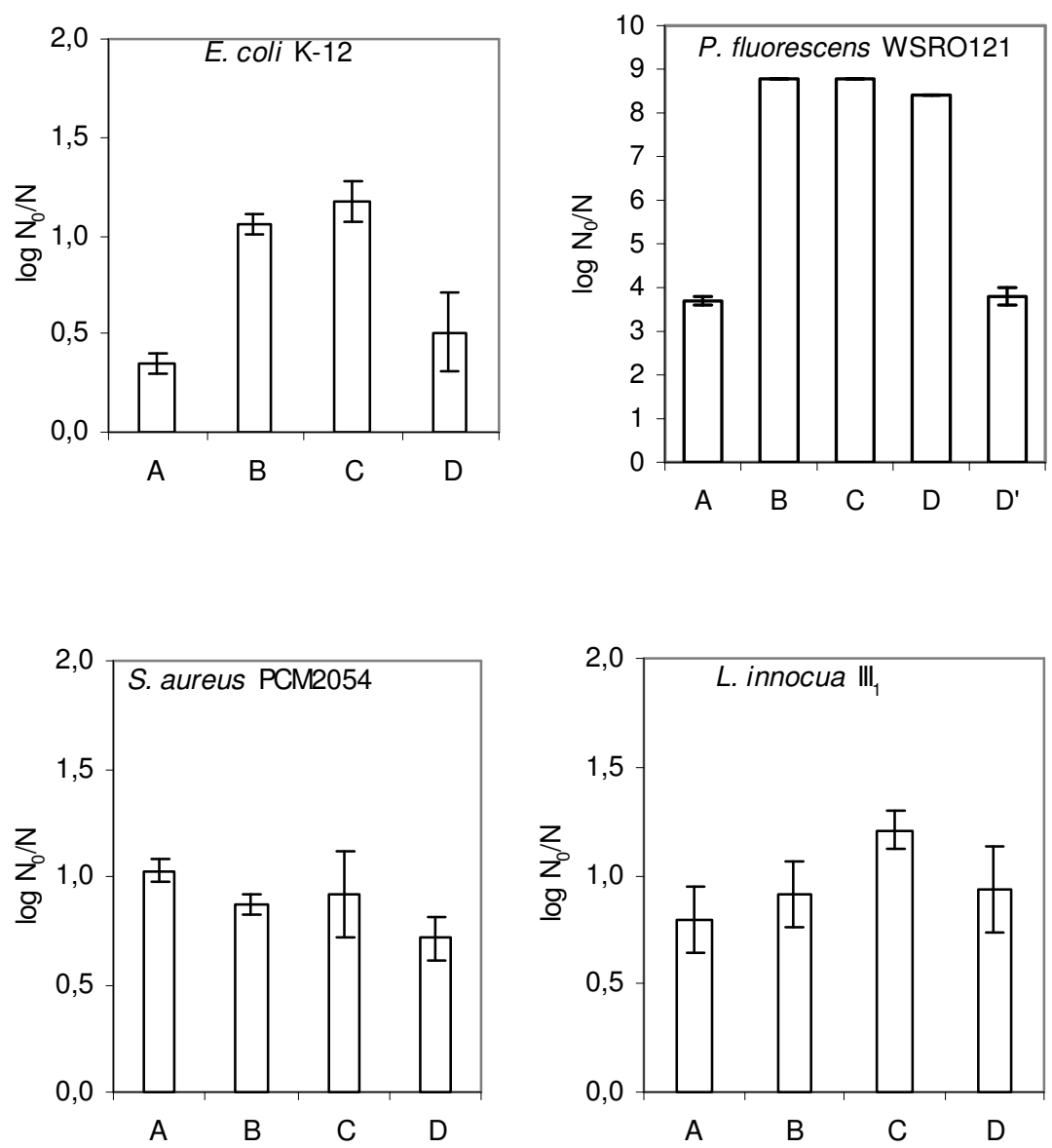

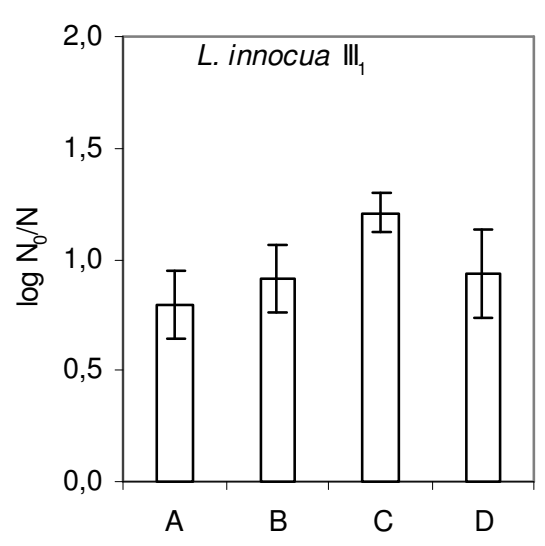

Figure 3. The effect of pressure $193 \mathrm{MPa}$ at $-20{ }^{\circ} \mathrm{C}$ and lysozyme $(400 \mu \mathrm{g} / \mathrm{ml})$ on the viability loss of some Gramnegative and Gram-positive of bacteria at stationary growth phase; A - pressurized sample without lysozyme; B pressurized sample with lysozyme; $\mathrm{C}$ - pressurized sample with lysozyme and subsequently incubated for $2 \mathrm{~h}$ at $37^{\circ} \mathrm{C}$; $\mathrm{D}$ - pressurized sample and subsequently incubated for $2 \mathrm{~h}$ at $37^{\circ} \mathrm{C}$ with added lysozyme; D' - sample with added lysozyme after pressure treatment and immediately plated on TSAYE

$\mathrm{N}_{0}$ - the number of cells in the control (about $10^{8}-10^{9}$ cfu/ml)

$\mathrm{N}-$ the number of cells detected after pressurization 
According to some authors $(13,22,23,24)$ the sensitization of Gram-negative bacteria to lysozyme or nisin under high pressure is a result of a transient permeabilization of the outer membrane. It means that bacteria show sensitivity to the antimicrobial substances only during pressurization. The results of the present study show also such an effect when the samples after pressure treatment were incubated for a short time, up to $2 \mathrm{~h}$ at $37^{\circ} \mathrm{C}$. During that time the level of bacteria inactivation did not increase (Fig 3). In the experiments of other authors with lysozyme added after pressure treatment the time of incubation did not exceed 180 min at $25^{\circ} \mathrm{C}(13,25)$. However, data presented in Table 2 indicate that the reduction of $E$. coli cells took place when storage time of samples pressurized in the presence of lysozyme was elongated to $20 \mathrm{~h}$. The number of viable cells of E. coli $\mathrm{K}-12$ at 37 and $5{ }^{\circ} \mathrm{C}$ was, respectively, 1.9 or 2.7 $\log$ cycles lower than that for samples pressurized and stored in the absence of lysozyme. It was also found that although there was no significant reduction in the number viable cells after $24 \mathrm{~h}$ of storage at $5^{\circ} \mathrm{C}$ of pressurized sample without lysozyme, sublethal injury of the cells was observed. The difference between the number of $E$. coli cells isolated from TSAYE and MacConkey selective medium increased from $0.1 \mathrm{log}$ cycle (unstored pressurized sample) to about $3 \mathrm{log}$ cycles after storage at $5^{\circ} \mathrm{C}$ (unpublished data). Furthermore, analysis of the data presented in Table 2 suggests that all sublethal injured cells remain sensitive to lysozyme.

The synergistic effect of high pressure and lysozyme was not observed in experiments with L. innocua and two strains of $S$. aureus. During storage for $24 \mathrm{~h}$ at 5 and $37{ }^{\circ} \mathrm{C}$ the number of viable cells of $S$. aureus PCM2054 pressurized in the presence of lysozyme decreased but only additive effect was evidenced (Table 2).

The highest effect of pressure $193 \mathrm{MPa}$ at $-20^{\circ} \mathrm{C}$ and lysozyme was found with pressure sensitive P. fluorescens; viable cells of this strain were not detected in $1 \mathrm{ml}$ of sample after combined treatment. Moreover, the results of the experiment with lysozyme added after pressure treatment of bacteria and immediately plated on agar medium showed that the level of inactivation of the tested bacteria was the same as that for the sample pressurized without lysozyme (Fig 3D' and A). These results again confirmed that lysozyme exerted antimicrobial activity during pressure treatment at low temperature. In addition, during storage of such samples for 2 $\mathrm{h}$ at $37^{\circ} \mathrm{C}$ further inactivation of bacteria was observed reaching the same level as in the case of bacteria pressurized in the presence of lysozyme. It indicates a large extent of sublethal damage of $P$. fluorescens cells.

Table 2. The effect of pressure $193 \mathrm{MPa}$ at $-20{ }^{\circ} \mathrm{C}$ and lysozyme $(400 \mu \mathrm{g} / \mathrm{ml})$ on the viability of $S$. aureus and $E$. coli cells at stationary growth phase, suspended in the buffer with $\mathrm{pH} 7.0^{1}$

\begin{tabular}{|c|c|c|c|}
\hline \multirow[b]{2}{*}{ Strain } & \multirow{2}{*}{ Sample } & \multicolumn{2}{|c|}{ Log CFU/ml of sample } \\
\hline & & $\begin{array}{l}\text { Without } \\
\text { lysozyme }\end{array}$ & $\begin{array}{c}\text { With } \\
\text { lysozyme }\end{array}$ \\
\hline \multirow{6}{*}{ 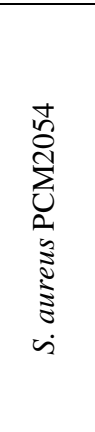 } & $\begin{array}{l}\text { Control (unpressurized and } \\
\text { unstored) }\end{array}$ & $8.8 \pm 0.1^{\mathrm{a}}$ & $8.7 \pm 0.2^{\mathrm{a}}$ \\
\hline & Control stored for $20 \mathrm{~h}$ at $5^{\circ} \mathrm{C}$ & $8.7 \pm 0.1^{\mathrm{a}}$ & $8.2 \pm 0.2^{\mathrm{c}}$ \\
\hline & Control stored for $20 \mathrm{~h}$ at $37^{\circ} \mathrm{C}$ & $8.6 \pm 0.3^{\mathrm{a}}$ & $8.3 \pm 0.2^{\mathrm{a}, \mathrm{c}}$ \\
\hline & Pressurized & $7.7 \pm 0.2^{\mathrm{b}}$ & $7.8 \pm 0.1^{\mathrm{b}}$ \\
\hline & $\begin{array}{l}\text { Pressurized and subsequently } \\
\text { stored for } 20 \mathrm{~h} \text { at } 5{ }^{\circ} \mathrm{C}\end{array}$ & $7.6 \pm 0.1^{\mathrm{b}}$ & $7.3 . \pm 0.1^{\mathrm{d}}$ \\
\hline & $\begin{array}{l}\text { Pressurized and subsequently } \\
\text { stored for } 20 \mathrm{~h} \text { at } 37^{\circ} \mathrm{C}\end{array}$ & $7.8 \pm 0.2^{\mathrm{b}}$ & $7.4 \pm 0.1^{\mathrm{d}}$ \\
\hline \multirow{6}{*}{ 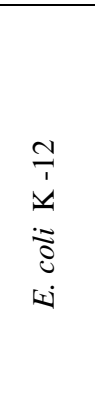 } & $\begin{array}{l}\text { Control (unpressurized and } \\
\text { unstored) }\end{array}$ & $8.6 \pm 0.1^{\mathrm{a}}$ & $8.6 \pm 0.1^{\mathrm{a}}$ \\
\hline & Control stored for $20 \mathrm{~h}$ at $5{ }^{\circ} \mathrm{C}$ & $8.5 \pm 0.1^{\mathrm{a}}$ & $8.0 \pm 0.0^{\mathrm{c}}$ \\
\hline & Control stored for $20 \mathrm{~h}$ at $37^{\circ} \mathrm{C}$ & $8.4 \pm 0.1^{\mathrm{a}, \mathrm{b}}$ & $8.0 \pm 0.1^{\mathrm{c}}$ \\
\hline & Pressurized & $8.2 \pm 0.1^{\mathrm{b}}$ & $7.5 \pm 0.3^{\mathrm{d}}$ \\
\hline & $\begin{array}{l}\text { Pressurized and subsequently } \\
\text { stored for } 20 \mathrm{~h} \text { at } 5^{\circ} \mathrm{C}\end{array}$ & $8.1 \pm 0.2^{b}$ & $5.4 \pm 0 . \mathrm{e}^{\mathrm{d}}$ \\
\hline & $\begin{array}{l}\text { Pressurized and subsequently } \\
\text { stored for } 20 \mathrm{~h} \text { at } 37^{\circ} \mathrm{C}\end{array}$ & $8.3 \pm 0.2^{\mathrm{a}, \mathrm{b}}$ & $6.4 \pm 0.1^{\mathrm{f}}$ \\
\hline
\end{tabular}

${ }^{1}$ For each bacterium, the values for a particular row or column followed by different letters differ significantly $(\mathrm{p}<0.05)$ 


\section{Antibacterial effect of high pressure and nisin}

Nisin at concentration of $100 \mu \mathrm{g} / \mathrm{ml}$ and $400 \mu \mathrm{g} / \mathrm{ml}$, pressure $193 \mathrm{MPa}$ at $-20{ }^{\circ} \mathrm{C}$ used separately or combined did not exert any bactericidal effect on S. aureus PCM2054 cells just after pressure treatment. Otherwise, E. coli was more sensitive to combined action of high pressure and nisin (Table 3). Synergistic reduction of these bacteria after pressure treatment in samples containing nisin at concentration of $400 \mu \mathrm{g} / \mathrm{ml}$ amounted to $1.7 \mathrm{log}$ cycles and was higher than in the case of lysozyme. According to Masschalck et al. (23) various compounds characterize different bactericidal spectra under pressure. However, in the present study less significant antimicrobial effect of high pressure at subzero temperature and lysozyme than pressure and nisin can result also from low enzymatic activity of lysozyme. Nisin working in different way than lysozyme can be more effective in inactivation of bacteria under these conditions.

Table 3. The effect of pressure $193 \mathrm{MPa}$ at $-20{ }^{\circ} \mathrm{C}$ and nisin on the viability of $S$. aureus and E. coli cells at stationary growth phase, suspended in the buffer with $\mathrm{pH} 7.0^{1}$

\begin{tabular}{|c|c|c|c|c|}
\hline \multirow[b]{2}{*}{ Strain } & \multirow{2}{*}{ Sample } & \multicolumn{3}{|c|}{ Log CFU/ml of sample } \\
\hline & & Without nisin & $\begin{array}{c}\text { With nisin } \\
(100 \mu \mathrm{g} / \mathrm{ml})\end{array}$ & $\begin{array}{c}\text { With nisin } \\
(400 \mu \mathrm{g} / \mathrm{ml})\end{array}$ \\
\hline \multirow{5}{*}{ 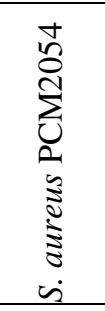 } & Control (unpressurized and unstored) & $8.8 \pm 0.1^{\mathrm{a}}$ & $8.7 \pm 0.2^{\mathrm{a}}$ & $8.7 \pm 0.2^{\mathrm{a}}$ \\
\hline & Control stored for $20 \mathrm{~h}$ at $5{ }^{\circ} \mathrm{C}$ & $8.5 \pm 0.1^{\mathrm{b}}$ & $8.3 \pm 0.2^{\mathrm{a}, \mathrm{b}}$ & $8.5 \pm 0.3^{\mathrm{a}, \mathrm{b}}$ \\
\hline & Pressurized & $8.1 \pm 0.1^{\mathrm{c}}$ & $7.9 \pm 0.1^{\mathrm{c}}$ & $8.1 \pm 0.3^{\mathrm{b}, \mathrm{c}}$ \\
\hline & $\begin{array}{l}\text { Pressurized and subsequently stored } \\
\text { for } 20 \mathrm{~h} \text { at } 5^{\circ} \mathrm{C}\end{array}$ & $7.8 \pm 0.1^{\mathrm{d}}$ & $8.2 \pm 0.1^{\mathrm{b}}$ & $6.9 \pm 0.1^{\mathrm{d}}$ \\
\hline & dunctored) & $84+03^{\mathrm{a}}$ & $84+02^{\mathrm{a}}$ & $84+02^{\mathrm{a}}$ \\
\hline & Control stored for $20 \mathrm{~h}$ at $5^{\circ} \mathrm{C}$ & $82+01^{\mathrm{a}}$ & $85+03^{\mathrm{a}}$ & $85+01^{\mathrm{a}}$ \\
\hline$\stackrel{1}{1}$ & Comition stored ior 20 in at & & & \\
\hline$\forall$ & Pressurized & $8.1 \pm 0.1^{\mathrm{a}}$ & $7.8 \pm 0.1^{\mathrm{b}}$ & $6.5 \pm 0.1^{\mathrm{c}}$ \\
\hline$\underset{0}{i}$ & $\begin{array}{l}\text { Pressurized and subsequently stored } \\
\text { for } 20 \mathrm{~h} \text { at } 5^{\circ} \mathrm{C}\end{array}$ & $8.2 \pm 0.1^{\mathrm{a}}$ & $7.7 \pm 0.1^{\mathrm{b}}$ & $6.1 \pm 0.1^{\mathrm{d}}$ \\
\hline
\end{tabular}

The results obtained by Steeg et al. (36) showed that bactericidal effect of combined pressure and nisin increased when treatment was conducted at temperature below $15^{\circ} \mathrm{C}$. The synergistic reduction of E. coli NCTC 9001 treated with pressure of $200 \mathrm{MPa}$ in the presence of nisin was above $3 \mathrm{log}$ cycles at $10{ }^{\circ} \mathrm{C}$ while at $40{ }^{\circ} \mathrm{C}$ only $0.3 \log$ cycle. The results of the present study show lower synergistic effect (Table 3), although temperature was lower than in the experiments carried out by Steeg et al. (36). These differences can result from higher sensitivity to high pressure of E. coli NCTC 9001 than of the strain E. coli NCTC 10538 used in our study. Masschalck et al. (23) reported that the sensitization of bacteria by high pressure to antimicrobial compounds varies even among strains belonging to the same species. Subsequently, the cell density in the present study was $10^{8} / 10^{9} \mathrm{cfu} / \mathrm{ml}$ while in that conducted by Stegg et al. (36) amounted to $10^{5} \mathrm{cfu} / \mathrm{ml}$. As found Garcia-Graells et al (9) E. coli was more sensitive to antimicrobial compounds like 
lactoperoxidase system and high pressure at low cell density $\left(10^{6} \mathrm{cfu} / \mathrm{ml}\right)$ than at high cell density $\left(10^{9} \mathrm{cfu} / \mathrm{ml}\right)$.

Table 4. The effect of pressure $193 \mathrm{MPa}$ at $-20{ }^{\circ} \mathrm{C}$ and nisin $(400 \mu \mathrm{g} / \mathrm{ml})$ on the viability of S. aureus and E. coli cells at stationary growth phase, suspended in the buffer with $\mathrm{pH} 5.0^{1}$

\begin{tabular}{|c|c|c|c|}
\hline \multirow[b]{2}{*}{ Strain } & \multirow[b]{2}{*}{ Sample } & \multicolumn{2}{|c|}{ Log CFU/ml } \\
\hline & & $\begin{array}{c}\text { Without } \\
\text { nisin }\end{array}$ & $\begin{array}{l}\text { With } \\
\text { nisin }\end{array}$ \\
\hline \multirow{5}{*}{ 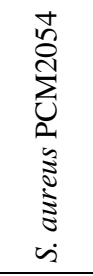 } & $\begin{array}{l}\text { Control (unpressurized and } \\
\text { unstored) }\end{array}$ & $8.3 \pm 0.3^{\mathrm{a}}$ & $7.6 \pm 0.1^{\mathrm{b}}$ \\
\hline & Control stored for $20 \mathrm{~h}$ at $5^{\circ} \mathrm{C}$ & $7.6 \pm 0.1^{\mathrm{b}}$ & $6.6 \pm 0.1^{\mathrm{c}}$ \\
\hline & Pressurized & $8.4 \pm 0.1^{\mathrm{a}}$ & $7.5 \pm 0.2^{\mathrm{b}}$ \\
\hline & $\begin{array}{l}\text { Pressurized and subsequently } \\
\text { stored for } 20 \mathrm{~h} \text { at } 5{ }^{\circ} \mathrm{C}\end{array}$ & $7.4 \pm 0.1^{\mathrm{b}}$ & $4.0 \pm 0.3^{\mathrm{d}}$ \\
\hline & & & \\
\hline \multirow{4}{*}{ 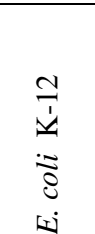 } & $\begin{array}{l}\text { Control (unpressurized and } \\
\text { unstored) }\end{array}$ & $8.3 \pm 0.1^{\mathrm{a}}$ & $8.0 \pm 0.2^{\mathrm{a}}$ \\
\hline & Control stored for $20 \mathrm{~h}$ at $5{ }^{\circ} \mathrm{C}$ & $8.2 \pm 0.1^{\mathrm{a}, \mathrm{b}}$ & $8.0 \pm 0.1^{\mathrm{a}}$ \\
\hline & Pressurized & $8.0 \pm 0.2^{\mathrm{a}, \mathrm{b}}$ & $8.1 \pm 0.1^{\mathrm{a}}$ \\
\hline & $\begin{array}{l}\text { Pressurized and subsequently } \\
\text { stored for } 20 \mathrm{~h} \text { at } 5{ }^{\circ} \mathrm{C}\end{array}$ & $7.9 \pm 0.2^{\mathrm{b}}$ & $7.1 \pm 0.1^{\mathrm{c}}$ \\
\hline
\end{tabular}

${ }^{1}$ For each bacterium, the values for a particular row or column followed by different letters differ significantly $(\mathrm{p}<0.05)$

Then, similarly as in experiments with lysozyme, there was the viability loss of E. coli and $S$. aureus during storage of the samples at $5{ }^{\circ} \mathrm{C}$, which were previously pressurized with nisin; the numbers of viable cells were decreased by 0.4 (E. coli) and $1.2 \log$ cycles (S. aureus) as compared with those just after pressure treatment. However, the inactivation of $E$. coli pressurized with nisin after 24 h storage was lower than that obtained in the case of lysozyme. On the other hand, taking into account higher antimicrobial effectiveness of nisin during pressurization than of lysozyme, the total reduction of E. coli was similar for both antimicrobial substances.

Gänzle et al. (7), reported that under ambient pressure the sensitivity of $E$. coli to nisin increased in acidic conditions. However, Steeg et al. (36) showed that antimicrobial effect of nisin and high pressure on $E$. coli
NCTC 9001 cells was much lower in samples at reduced $\mathrm{pH}$. According to the authors, the culture obtained at $\mathrm{pH} 7$ was treated by pressure at $\mathrm{pH} 4.5$ and the shock induced by $\mathrm{pH}$ drop probably reduced the transmembrane potential and in consequence the antimicrobial efficiency of nisin. In the present work the antimicrobial effect of pressure and nisin at pH 5 against E. coli cells just after pressure treatment was also much lower than that at $\mathrm{pH} 7$ (Table 3 and 4). However, the extent of the lethal effect during incubation of the sample after pressure treatment was higher. It can result from higher stability of nisin at acidic $\mathrm{pH}$ than at neutral $\mathrm{pH}(16,25)$. In the case of $S$. aureus the higher synergistic effect of pressure and nisin was obtained at $\mathrm{pH} 5$ as compared with that of $\mathrm{pH} 7$ and differences deepened during storage of the sample after pressure treatment at $5{ }^{\circ} \mathrm{C}$ (Table 3 and 4). S. aureus, in comparison to E. coli, was also more sensitive to acidic conditions and nisin during storage under ambient pressure. It is known that enteric bacteria are tolerant towards adverse environmental conditions such as low $\mathrm{pH}$ or other factors (7) and Gram-negative bacteria are more resistant to nisin than Gram-positive ones (3).

\section{CONCLUSIONS}

The data suggest that lysozyme exerts antimicrobial effect during pressurization at subzero temperature what points to non-lytic mechanisms of its action under these conditions. Further studies are needed to explain this phenomenon.

Pressurization of bacteria at subzero temperature in buffer solution leads to sublethal injury of bacterial cells during subsequent prolonged storage of the samples. In the consequence, these cells become sensitive to antimicrobial substance such as nisin and lysozyme.

Furthermore, the maximal pressure of about $200 \mathrm{MPa}$ that is possible to achieve in the sealed vessel at subzero 
temperature combined with nisin or lysozyme and refrigerated storage increases synergistically reduction of bacteria. However, such conditions can be insufficient to complete inactivation of vegetative microorganisms, especially in food system. Therefore, taking into account also the economical aspect of using high pressure, it would be worth searching for some other, more effective antimicrobials to extend the shelf-life and enhance the safety of food.

\section{ACKNOWLEDGEMENTS}

This research project was financed by the national research budget in the years 2003-2006.

\section{REFERENCES}

1. Alpas, H.; Kalchayanand, N.; Bozoglu, F.; Sikes, A.; Dunne, C.P.; Ray, B. (1999). Variation in resistance to hydrostatic pressure among strains of food-borne pathogens. Appl. Environ. Microbiol. 65, 4248-4251.

2. Bridgman, P.W. (1912). Water in the liquid and five solid forms under pressure. Proc. Amer. Acad. Arts. Sci. XLVII (1912), 439-558.

3. Cheftel, J.C. (1995). High pressure, microbial inactivation and food preservation. Food Sci. Technol. Int. 1, 75-90.

4. Cheftel, J.C.; Culioli, J. (1997). Effect of high pressure on meat: a reviev. Meat Sci. 46, 211-236.

5. Clarke, A.J.; Dupont, C. (1992). O-acetylated peptidoglycan: its occurrence, pathobiological significance, and biosynthesis. Can. J. Microbiol. 38, 85-91.

6. During, K.; Porsch, P.; Mahn, A.; Brinkmann O.; Gieffers, W. (1999). The non-enzymatic microbial activity of lysozymes. FEBS Lett. 449, 93-100.

7. Gänzle, M.G.; Weber, S.; Hammes, W.P. (1999). Effect of ecological factors on the inhibitory spectrum and activity of bacteriocins. Int. J. Food Microbiol. 46, 207-217.

8. García-Graells, C.; Masschalck, B.; Michiels, C.W. (1999). Inactivation of Escherichia coli in milk by high hydrostatic pressure treatment in combination with antimicrobial peptides. J. Food Protec. $62,1248-1254$.

9. García-Graells, C.; Van Opstal, I.; Vanmuysen, A.C.M.; Michiels, C.W. (2003). The lactoperoxidase system increases efficacy of high pressure inactivation of foodborne bacteria. Int. J. Food Microbiol. 81, 211-221.

10. García-Graells, C.; Valckx, C.; Michiels, C.W. (2000). Inactivation of Escherichia coli and Listeria innocua in milk by combined treatment with high hydrostatic pressure and the lactoperoxidase system. Appl. Environ. Microbiol. 66, 4173-4179.

11. Gervilla, R.; Felipe, X.; Ferragut, V.; Guamis, B. (1997). Effect of high hydrostatic pressure on Escherichia coli and Pseudomonas fluorescens strains in ovine milk. J. Dairy. Sci. 80, 2297-2303.

12. Hashizume, C.; Kimura, K.; Hayashi, R. (1995). Kinetic analysis of yeast inactivation by high pressure treatment at low temperatures. Biosci. Biotechnol. Biochem. 59, 1455-1458.

13. Hauben, K.J.A.; Bartlett, D.H.; Carine, C.; Soontjens, F.; Cornelis, K.; Wuytack, E.Y.; Michiels, Ch.W. (1997). Escherichia coli mutants resistant to inactivation by high hydrostatic pressure. Appl. Environ. Microbiol. 63, 945-950.

14. Hauben, K.J.A.; Wuytack, E.Y.; Soontjens, C.C.F.; Michiels, Ch. (1996). High-pressure transient sensitization of Escherichia coli to lysozyme and nisin by disruption of outer-membrane permeability. $J$. Food Protec. 59, 350-355.

15. Hayakawa, K.; Ueno, Y.; Kawamura, S.; Kato, T.; Hayashi, R. (1998). Microorganism inactivation using high pressure generation in sealed vessels under sub-zero temperature. Appl. Microbiol. Biotechnol. 50, 415-418.

16. Hurst, A. (1981). Nisin. Adv. Appl. Microbiol. 27, 85-123.

17. Kalchayanand, N.; Frethem, C.; Dunne, P.; Sikes, A.; Ray, B. (2002). Hydrostatic pressure and bacteriocin-triggered cell wall lysis of Leuconostoc mesenteroides. Innov. Food Sci. Emerg. Technol. 3, 33-40.

18. Kalchayanand, N.; Sikes, A.; Dunne, C.P.; Ray, B. (1998). Factors influencing death and injury of foodborne pathogens by hydrostatic pressure-pasteurization. Food Microbiol. 15, 207-214.

19. Kalchayanand, N.; Sikes, T.; Dunne, C.P.; Ray, B. (1994). Hydrostatic pressure and electroporation have increased bactericidal efficiency in combination with bacteriocins. Appl. Environ. Microbiol. 60, 41744177 .

20. Kalchayanand, N. Sikes, T.; Dunne, C.P.; Ray, B. (1998). Interaction of hydrostatic pressure, time and temperature of pressurization and pediocin $\mathrm{AcH}$ on inactivation of foodborne bacteria. J. Food Protec. $61,425-431$.

21. Linton, M.; McClements, J.M.J.; Patterson, M.F. (2001). Inactivation of pathogenic Escherichia coli in skimmed milk using high hydrostatic pressure. Innov. Food Sci. Emerg. Technol. 2, 99-104.

22. Masschalck, B.; García-Graells, C.; Van Haver, E.; Michiels, C.W. (2000). Inactivation of high pressure resistant Escherichia coli by 
lysozyme and nisin under high pressure. Innov. Food Sci. Emerg. Technol. 1, 39-47.

23. Masschalck, B.; Van Houdt, R. Michiels, Ch. (2001). High pressure increases bactericidal activity and spectrum of lactoferrrin, lactoferricin and nisin. Int. J. Food Microbiol. 64, 325-332.

24. Masschalck, B.; Van Houdt, R.; Van Haver, E.; Michiels, Ch. (2001). Inactivation of gram-negative bacteria by lysozyme, denaturated lysozyme and lysozyme-derived peptides under high hydrostatic pressure. Appl. Environ. Microbiol. 67, 339-344.

25. Moreno, I.; Lerayer, A.L.S.; Baldini, V.L.S.; de F. Leitão, M.F. (2000). Characterization of bacteriocins produced by Lactococcus lactis strains. Braz. J. Microbiol. 31, 184-192.

26. Moussa, M.; Perrier-Cornet, J.M.; Gervais, P. (2006). Synergistic and antagonistic effects of combined subzero temperature and high pressure on inactivation of Escherichia coli. Appl. Environ. Microbiol. 72, 150156.

27. Nakimbugwe, D.; Masschalck, B.; Atanassova, M.; Zewdie-Bosuner, A.; Michiels, C.W. (2006). Comparison of bactericidal activity of six lysozymes at atmospheric pressure and under high hydrostatic pressure. Int. J. Food Microbiol. 108, 355-363.

28. Pagan, R.; Mackey, B. (2000). Relationship between membrane damage and cell death in pressure treated Escherichia coli cells: differences between exponential- and stationary-phase cells and variation among strains. Appl. Environ. Microbiol. 66, 2829-2834.

29. Patterson, M.F.; Quinn, M.; Simpson, R.; Gilmour, A. (1995).
Sensitivity of vegetative pathogens to high hydrostatic pressure treatment in phosphate-buffered saline and foods. J. Food Protec. 58, 524-529.

30. Pellegrini, A.; Thomas, U.; von Fellenberg, R.; Wild, P. (1992). Bactericidal activities of lysozyme and aprotinin against gram-negative and gram-positive bacteria related to their basic character. J. Appl. Bacteriol. 72, 180-187.

31. Perrier-Cornet, J.M.; Tapin, S.; Gaeta, S.; Gervais, P. (2005). High pressure inactivation of Saccharomyces cerevisiae and Lactobacillus plantarum at subzero temperatures. J. Biotech. 115, 405-412.

32. Ponce, E.; Pla, R.; Mor-Mur, M.; Gervilla, R.; Guamis, B. (1998). Inactivation of Listeria innocua inoculated in liquid whole egg by high hydrostatic pressure. J. Food Protec. 61, 119-122.

33. Reyns, K.M.F.A.; Sootjens, C.C.F.; Cornelis, K.; Weemaes, C.A.; Hendrickx E.; Michiels, C.W. (2000). Kinetic analysis and modeling of combined high-pressure-temperature inactivation of the yeast Zygosaccharomyces bailii. Int. J. Food Microbiol. 56, 199-210.

34. Simpson, R.K.; Gilmour A. (1997). The resistance of Listeria monocytogenes to high hydrostatic pressure in foods. Food Microbiol. 14, 567-573.

35. Smelt, J.P.P.M. (1998). Recent advances in the microbiology of high pressure processing. Trends Food Sci. Technol. 9, 152-158.

36. Steeg ter, P.F.; Hellemons, J.C.; Kok, A.E. (1999). Synergistic actions of nisin, sublethal ultrahigh pressure and reduced temperature on bacteria and yeast. Appl. Environ. Microbiol. 65, 4148-4154. 